\title{
Serum concentrations of adipokines in men with prostate cancer and benign prostate hyperplasia
}

\author{
Stężenia adipokin u mężczyzn z rakiem prostaty i z łagodnym przerostem \\ prostaty
}

\section{Lucyna Siemińska ${ }^{1}$, Artur Borowski ${ }^{2}$,Bogdan Marek1 , Mariusz Nowak', Dariusz Kajdaniuk', Jakub Warakomski ${ }^{1}$, Beata Kos-Kudła ${ }^{1}$}

${ }^{1}$ Department of Pathophysiology and Endocrinology, School of Medicine with the Division of Densitry in Zabrze, Medical University of Silesia, Zabrze, Poland

${ }^{2}$ The Silesia Urology Centre Urovita, Chorzów, Poland

\begin{abstract}
Introduction: Obesity and prostate cancer are related, but the causal relationship remains unknown. The aim of the study was to compare concentrations of leptin, adiponectin and chemerin in patients with prostate cancer and benign prostate hyperplasia and to examine associations of the adipokines with the grade of prostate cancer, interleukin-6 (IL-6), insulin resistance and anthropometric and metabolic variables.

Material and methods: The study group consisted of 140 men divided into two groups: I- prostate cancer $(n=74)$ and II - with benign hyperplasia $(n=66)$. Serum leptin, adiponectin, chemerin, IL-6 and metabolic profile were measured. Considering histological differentiation prostate cancer patients were divided into 3 subgroups: well differentiated (Gleason score $\leq 6$ ), moderately differentiated subgroup (Gleason 7), and poorly differentiated (Gleason $\geq 8$ ).

Results: There were no differences between groups in BMI, waist circumference, HOMA-I, serum levels of total cholesterol, glucose, triglycerides, adiponectin, leptin and chemerin. However, the concentrations of PSA, IL-6 and leptin-to-adiponectin ratio were significantly higher in cancer group compared with benign hyperplasia group. In the poorly differentiated cancer subgroup, subjects had higher PSA, leptin, chemerin, IL-6 and triglycerides concentrations as well as higher leptin-to-adiponectin ratio. Overweight and obese men with prostate cancer were more likely to have moderately or poorly differentiated cancer. In the all men serum adiponectin was significantly correlated with HOMA-I, BMI, glucose, triglycerides, cHDL. There were significant correlations between leptin and BMI, HOMA-I, waist circumference, glucose, triglycerides and cHDL. Among all the participants we observed associations between chemerin and waist, triglycerides and leptin-to-adiponectin ratio. In prostate cancer patients chemerin correlated with IL-6 and leptin as well as with leptinto-adiponectin ratio. We measured significant positive correlations between Gleason score and chemerin, leptin concentrations and leptin-to-adiponectin ratio. There were positive correlations between adiponectin and PSA levels in cancer group, as well as in all men. Conclusions: Leptin-to-adiponectin ratio and IL-6 concentration were elevated in men with prostate cancer. Leptin, chemerin, IL-6 and leptin-to-adiponectin ratio were associated with Gleason score. In prostate cancer men the relationships between serum leptin, chemerin, IL-6 and leptin-to-adiponectin ratio were dependent on each other. Overweight and obese men with prostate cancer had a higher Gleason score. (Endokrynol Pol 2018; 69 (2): 120-127)
\end{abstract}

Key words: obesity, prostate cancer, adiponectin, leptin, chemerin, interleukin-6

\section{Streszczenie}

Wstęp: Nie do końca są poznane mechanizmy wiążące otyłość i raka prostaty. Celem pracy było porównanie stężeń leptyny, adiponektyny i chemeryny u pacjentów $\mathrm{z}$ rakiem prostaty i łagodnym przerostem prostaty oraz ocena powiązań pomiędzy adipokinami i stopniem zróżnicowania Gleasona, interleukiną-6 (IL-6), opornością insulinową oraz antropometrycznymi i metabolicznymi parametrami.

Materiał i metody: Do badania włączono 140 mężczyzn, których w zależności od wyniku biopsji podzielono na 2 grupy: I z rakiem prostaty $(\mathrm{n}=74)$ i II z lagodnym przerostem $(\mathrm{n}=66)$. Oceniano stężenia leptyny, adiponektyny, chemeryny, IL-6 oraz profil metaboliczny. Na podstawie wyniku biopsji pacjentów z rakiem prostaty podzielono na 3 podgrupy: rak dobrze zróżnicowany (skala Gleasona $\leq 6$ ), rak średnio zróżnicowany (skala Gleasona 7) i rak źle zróżnicowany (skala Gleasona $\geq 8$ ).

Wyniki: Gdy porównano obie grupy nie stwierdzono różnic w BMI, w obwodzie talii, HOMA-I, w stężeniu cholesterolu, glukozy, trójglicerydów, leptyny, adiponektyny i chemeryny. Stężenie PSA, IL-6 oraz wskaźnik leptyna-adiponektyna były istotnie wyższe u mężczyzn z rakiem niż z przerostem prostaty. U pacjentów z rakiem o najwyższym stopniu złośliwości występowały wyższe stężenia PSA, leptyny, chemeryny, IL-6 i trójglicerydów, wyższy też był wskaźnik leptyna-adiponektyna. U osób z nadwagą i otyłością istotnie częściej występował rak średnio lub źle zróżnicowany. U wszystkich badanych stężenie adiponektyny istotnie korelowało z HOMA-I, BMI, glukozą, trójglicerydami i cHDL. Stwierdzono korelacje pomiędzy leptyną, BMI, HOMA-I, obwodem w talii, glukozą, trójglicerydami i cHDL. Wśród wszystkich badanych obserwowano powiązania pomiędzy chemeryną i obwodem w talii oraz trójglicerydami i wskaźnikiem leptyna-adiponektyna. U pacjentów z rakiem prostaty chemeryna korelowała z IL-6 i leptyną a także ze wskaźnikiem leptyna-adiponektyna. Stwierdzono statystycznie istotne powiązania pomiędzy złośliwością raka prostaty ocenianą w skali Gleasona oraz stężeniem chemeryny i leptyny oraz wskaźnikiem leptyna-adiponektyna. Dodatnią korelację pomiędzy adiponektyną i PSA wykryto u mężczyzn $\mathrm{z}$ rakiem prostaty oraz $\mathrm{u}$ wszystkich badanych.

Lucyna Siemińska M.D., Ph.D., Department of Pathophysiology and Endocrinology, School of Medicine with the Division of Densitry in Zabrze, Medical University of Silesia, Traugutta St. 2, 41-800 Zabrze, Poland, e-mail: lusiem@poczta.onet.pl 
Wnioski: Wskaźnik leptyna-adiponektyna oraz stężenie IL-6 były wyższe u mężczyzn z rakiem prostaty niż w łagodnym przeroście. Leptyna, chemeryna, IL-6 oraz wskaźnik leptyna-adiponektyna były powiązane ze skalą Gleasona. U pacjentów z rakiem prostaty stwierdzono wzajemne powiązania między stężeniem chemeryny, leptyny, IL-6 i wskaźnikiem leptyna-adiponektyna. Mężczyzn z nadwagą i otyłością charakteryzował niższy stopień zróżnicowania raka oceniany w skali Gleasona. (Endokrynol Pol 2018; 69 (2): 120-127)

Słowa kluczowe: otyłość; rak prostaty; adiponektyna; leptyna; chemeryna; interleukina-6

\section{Introduction}

Different factors including age, low physical activity, dietary habits and family history favor the development of prostate cancer. Obesity or being overweight are recognized as a risk factors for prostate cancer [1]. Although the mechanisms underlying those associations are not fully recognized, it may be possible that insulin resistance, chronic inflammation and excess of adipose tissue or/and its dysfunction, known as adiposopathia, foster prostate cancerogenesis [2]. Adipokines produced by adipose tissue influence in metabolic processes and they mediate inflammation, cell proliferation and angiogenesis. The most abundant adipokines are leptin and adiponectin. In obesity, changes in their secretion may be associated with cancerogenesis [2]. Leptin serum levels are closely correlated with adipose tissue mass. The stimulating role of leptin in chronic inflammation, neoangiogenesis and tumorigenesis is established. The overexpression of leptin and its receptors has been well documented in numerous types of cancer $[2,3]$. Another hormone which is secreted by adipose tissue is adiponectin. Various studies have been carried out to evaluate the relationships between adiponectin and cancerogenesis and most of them have reported that hypoadiponectinemia promotes tumor cell proliferation and influences mitogenic growth factors [2]. Chemerin is the next newly identified adipokine secreted by adipose tissue which may be associated with cancerogenesis. To our knowledge, there are no studies assessing circulating chemerin levels in patients with prostate cancer. Interleukin-6 (IL-6) is another cytokine produced by adipose tissue which serum levels are increased in obesity. This proinflammatory cytokine is involved in cancerogenesis by modulating cellular proliferation, invasion and angiogenesis. Previous studies regarding relationships between IL- 6 and prostate cancer have reported essential role of this cytokine in development and progression of prostate cancer $[4,5]$.

Large prospective studies [1] reveal that excess body adiposity promotes not only cancerogenesis but is also associated with increased risk of benign prostate hyperplasia. However, in molecular aspect, benign prostate hyperplasia and prostate cancer present two separate pathophysiological pathways and there are no direct relationships between those diseases. The common future of both diseases are hormonal dependence, slow progression and prostatic inflammation. However, it is not known whether links connecting obesity and prostate cancer and benign prostate hyperplasia are exactly the same. Therefore, the next aim of the study is to compare links connecting obesity and adipokines in group of patients with prostate cancer and benign prostate hyperplasia.

The specific goals of the study are:

1. Determining serum concentrations of adipokines: leptin, adiponectin, chemerin and inflammatory cytokine IL-6 in patients with prostate cancer and with benign prostate hyperplasia.

2. Evaluating associations between adipokines and histological types of prostate cancer.

3. Estimating the relationships between obesity, insulin resistance, inflammation and examined adipokines in both groups.

\section{Material and methods}

Our prospective study was conducted on 140 men treated at Urology Hospital UROVITA in Chorzow in 2014. All subjects who participated in the study gave the agreement in the written form. The study was approved by the local Ethical Review. Biopsies were performed by urologists with transrectal ultrasound.

Depending on the results of histology findings, men were divided into two groups: I - prostatic cancer $(\mathrm{n}=74)$ and II - with pathologic hyperplasia $(\mathrm{n}=66)$, both groups were matched by BMI.

Exclusion criteria for both groups were: diabetes mellitus, heart, renal or liver failures and diagnosis of cancer other than prostate cancer. In all men anthropometric measurements were done: BMI was calculated as ratio of weight to square of height. Waist circumferences were measured. Blood samples were obtained in the morning time in fasting condition. Serum samples were stored frozen in $-70^{\circ} \mathrm{C}$. In all participants metabolic profile was assessed (lipid profile and glucose concentrations) using enzymatic method. Serum leptin, adiponectin, chemerin and IL-6 concentrations were measured by ELISA methods using commercial assays. Leptin-to-adiponectin ratio was calculated as leptin in $\mathrm{ng} / \mathrm{mL}$ divided by adiponectin in $\mathrm{ug} / \mathrm{mL}$. Serum PSA concentrations were assessed using immunochemical method (ECLIA). HOMA-I was calculated with formula: HOMA-I = fasting serum glucose concentration $(\mathrm{mg} / \mathrm{dL}) / 18.1 \times$ fasting serum insulin concentration 
$(\mathrm{uIU} / \mathrm{mL}) / 22.5$ [6]. In the current study for diagnosis of insulin resistance we have used threshold value HOMA-I $\geq 2.5$, as other researches [7].

Prostate cancer subjects were further subdivided according to BMI (values $\leq 25, \leq 30$, and $>30$ ).

Considering histological differentiation prostate cancer patients were then divided into 3 subgroups according to the Gleason score: well differentiated (Gleason score $\leq 6)$, moderately differentiated subgroup (Gleason 7), and poorly differentiated (Gleason $\geq 8$ ).

Statistical analysis were performed using STATISTICA 12.0, StatSoft Inc. Data were tested for normal distribution using W Shapiro-Wilk test. The results are presented as mean values with standard deviations and medians. Groups were compared by Student's test or U Mann-Whitney test. Correlations between variables were estimated by calculating the correlation coefficient R by Pearson`s method or Spearman`s method. The prevalence of obesity and insulin resistance were compared using chi-squared test. Logistic regression analysis was used to estimated the odds ratios and 95\% CI to evaluate the association between Gleason score (Gleason $\leq 6$ vs. $\geq 7$ ) and BMI ( $<25$ vs. $\geq 25$ ). All results were considered as statistically significant with $p<0.05$.

\section{Results}

In the first part of the study we have analyzed the data from all 140 subjects according to the histological finding (group I - cancer, group II - benign hyperplasia). The characteristics of men are summarized in Table I.

Statistical analysis showed that mean age of cancer group was higher than in hyperplasia group (67.13 \pm 8.48 versus $61.51 \pm 10.30$ ). The mean $\mathrm{BMI}$ in group I was $27.90 \pm 3.27$ and was similar to group II $(27.25 \pm$ 3.97). There were no differences between groups in waist circumference, HOMA-I, serum levels of total cholesterol, glucose, triglycerides, adiponectin, leptin and chemerin. However, as shown in Table I, the concentrations of PSA, IL-6 and leptin-to-adiponectin ratio were significantly higher in cancer group compared with benign hyperplasia group.

The prevalence of subjects with BMI $>30$ did not differ between group I and II $(24.32 \%, \mathrm{n}=18 \mathrm{vs.} 22.73 \%$, $\mathrm{n}=15$, respectively). The proportions of overweight men, defined as $25-30 \mathrm{~kg} / \mathrm{m}^{2}$, were also similar (55.45\%, $\mathrm{n}=41$ in cancer group, $48.48 \%, \mathrm{n}=32$ in benign prostate hyperplasia group). The proportions of normal BMI men $\left(\right.$ BMI $\left.<25 \mathrm{~kg} / \mathrm{m}^{2}\right)$, were similar $(20.27 \%, \mathrm{n}=15$ in group I, $28.79 \%, \mathrm{n}=19$ in group II). The prevalence of insulin resistance was similar in both groups - it was recognized in $58 \%, \mathrm{n}=43$ prostate cancer patients and in $54.4 \%, \mathrm{n}=36$ benign prostate hyperplasia patients. Table II shows the clinical and biochemical characteristics of patients by prostate cancer severity. In the poorly differentiated cancer subgroup, subjects were older, had higher PSA, leptin, chemerin, IL-6 and triglycerides concentrations and higher leptin-to-adiponectin ratio.

Table I. Clinical and biochemical characteristics of men with prostate cancer (group I) and with benign prostate hyperplasia (group II)

Tabela I. Kliniczna i biochemiczna charakterystyka mężczyzn z rakiem prostaty = grupa I oraz łagodnym przerostem gruczołu krokowego $=$ grupa II

\begin{tabular}{|c|c|c|c|}
\hline & $\begin{array}{l}\text { Prostate cancer (group I) } \\
\mathrm{n}=74\end{array}$ & $\begin{array}{l}\text { Benign prostate hyperplasia (group II) } \\
\mathrm{n}=66\end{array}$ & $\mathbf{P}$ \\
\hline Age & $67.13 \pm 8.48[67.0]$ & $61.51 \pm 10.30[60.0]$ & $<0.001$ \\
\hline BMI $\left[\mathrm{kg} / \mathrm{m}^{2}\right]$ & $27.90 \pm 3.27[28.07]$ & $27.25 \pm 3.97[26.68]$ & Ns \\
\hline Waist [cm] & $102.35 \pm 9.81[102.0]$ & $101.77 \pm 9.27[101.0]$ & Ns \\
\hline Glucose [mg/dL] & $104.31 \pm 27.97[102.5]$ & $108.15 \pm 33.35[98.0]$ & Ns \\
\hline Cholesterol [mg/dL] & $186.5 \pm 46.91[184.5]$ & $186.54 \pm 45.61[186.5]$ & Ns \\
\hline CHDL [mg/dL] & $47.24 \pm 13.85[45.0]$ & $50.36 \pm 22.47[47.5]$ & Ns \\
\hline Triglycerides [mg/dL] & $124.49 \pm 49.09[115.0]$ & $138.12 \pm 91.32[111.0]$ & Ns \\
\hline HOMA-I & $3.94 \pm 4.27[3.28]$ & $5.32 \pm 8.19[3.07]$ & Ns \\
\hline Adiponectin [ug/mL] & $18.28 \pm 8.08[16.0]$ & $17.83 \pm 8.63[16.32]$ & Ns \\
\hline Leptin [ng/mL] & $9.79 \pm 8.27[7.87]$ & $9.03 \pm 7.26[7.82]$ & Ns \\
\hline Leptin-to-adiponectin ratio & $0.68 \pm 0.70[0.49]$ & $0.64 \pm 0.60[0.46]$ & $<0.05$ \\
\hline Chemerin $[\mathrm{ng} / \mathrm{mL}]$ & $273.48 \pm 78.81[268.7]$ & $267.98 \pm 83.46[253.3]$ & Ns \\
\hline IL-6 [pg/mL] & $17.30 \pm 31.14[7.23]$ & $11.75 \pm 20.66[4.24]$ & $<0.01$ \\
\hline PSA [ng/mL] & $33.71 \pm 89.82[8.0]$ & $3.74 \pm 5.41[1.48]$ & $<0.001$ \\
\hline
\end{tabular}

Data were given as mean \pm SD, and median. Groups were compared by Student`s test or U Mann-Whitney test 
Table II. The clinical and biochemical characteristics of patients by prostate cancer severity

Tabela II. Charakterystyka kliniczno-biochemiczna pacjentów z rakiem prostaty $w$ zależności do nasilenia procesu nowotworowego

\begin{tabular}{|c|c|c|c|}
\hline & $\begin{array}{l}\text { Well differentiated prostate cancer } \\
\text { subgroup (Gleason score } \leq 6, n=24 \text { ), }\end{array}$ & $\begin{array}{l}\text { Moderately differentiated cancer } \\
\text { subgroup (Gleason } 7, n=28 \text { ) }\end{array}$ & $\begin{array}{l}\text { Poorly differentiated cancer } \\
\text { subgroup (Gleason } \geq 8, n=22 \text { ) }\end{array}$ \\
\hline Age & $64.62 \pm 8.49[65.6]$ & $66.75 \pm 8.75[66.5]$ & $70.24 \pm 7.53[68.0]^{*}$ \\
\hline BMI $\left[\mathrm{kg} / \mathrm{m}^{2}\right]$ & $27.19 \pm 3.62[27.12]$ & $28.04 \pm 2.81[27.08]$ & $28.32 \pm 3.38[28.10]$ \\
\hline Waist [cm] & $101.42 \pm 9.30[100.50]$ & $101.32 \pm 9.75[100.50]$ & $104.09 \pm 10.32[104.00]$ \\
\hline Glucose [mg/dL] & $107.29 \pm 41.56[104.0]$ & $103.86 \pm 21.51[101.0]$ & $99.52 \pm 11.12[103.0]$ \\
\hline Cholesterol [mg/dL] & $170.12 \pm 51.53[165.5]$ & $199.25 \pm 46.86[202.0]$ & $188.95 \pm 38.03[184.0]$ \\
\hline $\mathrm{CHDL}[\mathrm{mg} / \mathrm{dL}]$ & $48.79 \pm 12.56[51.5]$ & $47.28 \pm 16.31[42.5]$ & $45.52 \pm 12.38[43.0]$ \\
\hline Triglycerides [mg/dL] & $113.79 \pm 47.60[98.0]$ & $122.82 \pm 29.81$ [117.5] & $136.81 \pm 67.74[116.0]^{*}$ \\
\hline HOMA-I & $3.28 \pm 2.31[2.64]$ & $4.63 \pm 6.22[3.51]$ & $3.69 \pm 2.52[3.09]$ \\
\hline Adiponectin [ug/mL] & $17.53 \pm 8.35[16.0]$ & $19.13 \pm 9.19[16.29]$ & $18.29 \pm 6.28[17.0]$ \\
\hline Leptin [ng/mL] & $7.73 \pm 7.01[5.65]$ & $8.98 \pm 6.10[8.33]$ & $13.34 \pm 11.20[9.69]^{*}$ \\
\hline Leptin-to-adiponectin ratio & $0.46 \pm 0.29[0.30]$ & $0.64 \pm 0.54[0.52] \wedge$ & $0.85 \pm 0.87[0.63]^{* * * \varepsilon}$ \\
\hline Chemerin [ng/mL] & $237.44 \pm 72.43$ [238.55] & $273.94 \pm 59.91[262.35]^{\wedge}$ & $312.80 \pm 92.60[286.6]^{* * 8}$ \\
\hline PSA [ng/mL] & $16.21 \pm 41.22[5.61]$ & $16.56 \pm 27.72[6.82]$ & $76.94 \pm 152.75[19.0]^{* * * \varepsilon}$ \\
\hline IL-6 & $15.78 \pm 19.87[7.63]$ & $17.91 \pm 29.03[8.71]^{\wedge}$ & $18.88 \pm 44.56[6.33]^{*}$ \\
\hline
\end{tabular}

Data were given as mean \pm SD, and median. Groups were compared by Student`s test or U Mann-Whitney test

${ }^{*} \mathrm{P}<0.05$ - poorly differentiated cancer subgroup vs well differentiated prostate cancer subgroup

${ }^{* * P}<0.01$ - poorly differentiated cancer subgroup vs well differentiated prostate cancer subgroup

${ }^{* *} \mathrm{P}<0.001$ - poorly differentiated cancer subgroup vs well differentiated prostate cancer subgroup

$\wedge P<0.05$ - moderately differentiated cancer subgroup vs well differentiated prostate cancer subgroup

\&p $<0.05$ - poorly differentiated cancer subgroup vs moderately differentiated cancer subgroup

Then logistic regression analysis was performed to calculate odds ratio (OR) for the presence of moderately and poorly differentiated PC (Gleason score $\geq 7$ ). Cases with BMI $\geq 25$ tended to have higher Gleason score. Odds ratio for subjects with BMI $\geq 25$ was 3.11 (95\% confidence interval CI 1.01-9.52).

In the next step of the study we assessed the correlations of serum adipokines with analyzed variables in all participants, as well as in both groups separately (Table III).

In the all men serum adiponectin was significantly correlated with HOMA-I, BMI, glucose, triglycerides, cHDL (Table III). There were strong significant correlations between leptin and BMI, HOMA-I, waist, glucose, triglycerides and cHDL. Among all the participants we observed associations between chemerin and waist as well as triglycerides. In prostate cancer patients chemerin correlated also with IL-6 $(\mathrm{R}=0.17, \mathrm{p}<0.05)$ and leptin $(\mathrm{R}=0.22, \mathrm{p}<0.01)-$ Figure I. We also measured a significant positive correlation between serum chemerin and Gleason score $(R=0.32, p<0.01)$, as well as between serum leptin and Gleason score $(\mathrm{R}=0.20, \mathrm{p}<0.05)$. There was a positive correlation between adiponectin and PSA levels in all men $(R=0.32$, $\mathrm{P}<0.001)$, as well as in cancer group $(R=0.27, \mathrm{p}<0.01)$.

\section{Discussion}

Obesity is associated with increased risk of various cancers including: breast, renal, colon, corpus uteri and prostate [2, 8]. It is estimated that in 2012 about $3.6 \%$ of all new cases of cancer in adults can be attributed to high BMI [9]. There is a gradual increase of prostate cancer incidence, especially in developed countries, according to increasingly Western eating abits. Accumulating evidences suggest that visceral obesity is associated with higher risk of progression and recurrence of prostate cancer [10, 11]. However, several studies have given contradictory results and have failed to confirm the associations between greater BMI and worse prostate cancer prognosis [12,13]. Our results are concordant with previous studies which determined that obesity is associated with higher aggressiveness. In our study the association between BMI and prostate cancer upgrading based on Gleason sum has been revealed. We have found that overweight and obese men with prostate cancer were three times more likely to have Gleason score $\geq 7$ than those with normal BMI. Of note, this study was not conducted among random population because the studied group included men from Silesian population, which is 
Table III. Correlations of adipokines: adiponectin, leptin and chemerin with selected anthropometric and biochemical variables in all men, in prostate cancer and in benign prostate hyperplasia patients

Tabela III. Korelacje pomiędzy stężeniem adiponektyny, leptyny i chemeryny oraz wybranych parametrów antropometrycznych $i$ biochemicznych $u$ wszystkich badanych, $z$ rakiem prostaty $i z$ tagodnym przerostem gruczotu krokowego

Correlations between HOMA index and serum concentrations of adipokines

\begin{tabular}{|c|c|c|c|}
\hline & Leptin & Adiponectin & Chemerin \\
\hline All the participants & $\mathrm{R}=0.47, \mathrm{p}<0.001$ & $R=-0.29 . p<0.001$ & $\mathrm{R}=0.13, \mathrm{p}=\mathrm{NS}$ \\
\hline Prostate cancer & $\mathrm{R}=0.53, \mathrm{p}<0.001$ & $R=-0.23, p=0.05$ & $\mathrm{R}=0.15, \mathrm{p}=\mathrm{NS}$ \\
\hline Prostate hypertrophia & $R=0.40, p<0.001$ & $\mathrm{R}=-0.36, \mathrm{p}<0.01$ & $\mathrm{R}=0.10, \mathrm{p}=\mathrm{NS}$ \\
\hline \multicolumn{4}{|c|}{ Correlations between $\mathrm{BMI}$ and serum concentrations of adipokines } \\
\hline All the participants & $R=0.55, p<0.001$ & $R=-0.11, p=N S$ & $\mathrm{R}=0.11, \mathrm{p}=\mathrm{NS}$ \\
\hline Prostate cancer & $\mathrm{R}=0.38, \mathrm{p}<0.001$ & $R=-0.26, p=0.02$ & $R=0.19, p=0.05$ \\
\hline Prostate hypertrophia & $\mathrm{R}=0.74, \mathrm{p}<0.001$ & $R=0.08, p=N S$ & $\mathrm{R}=-0.03, \mathrm{p}=\mathrm{NS}$ \\
\hline \multicolumn{4}{|c|}{ Correlations between waist circumference and serum concentrations of adipokines } \\
\hline All the participants & $R=0.54, p<0.001$ & $R=-0.05, p=N S$ & $\mathrm{R}=0.19, \mathrm{p}<0.01$ \\
\hline Prostate cancer & $R=0.46, p<0.001$ & $R=-0.23, p<0.05$ & $\mathrm{R}=0.17, \mathrm{p}<0.05$ \\
\hline Prostate hypertrophia & $\mathrm{R}=0.28, \mathrm{p}<0.01$ & $R=-0.14, p=N S$ & $\mathrm{R}=0.04, \mathrm{p}=\mathrm{NS}$ \\
\hline \multicolumn{4}{|c|}{ Correlations between serum concentrations of IL -6 and adipokines } \\
\hline All the participants & $\mathrm{R}=0.10, \mathrm{p}=\mathrm{NS}$ & $\mathrm{R}=-0.04, \mathrm{p}=\mathrm{NS}$ & $\mathrm{R}=0.13, \mathrm{p}=\mathrm{NS}$ \\
\hline Prostate cancer & $\mathrm{R}=0.14, \mathrm{p}<0.05$ & $\mathrm{R}=-0.01, \mathrm{p}=\mathrm{NS}$ & $\mathrm{R}=0.17, \mathrm{p}<0.05$ \\
\hline Prostate hypertrophia & $\mathrm{R}=0.24, \mathrm{p}<0.05$ & $\mathrm{R}=-0.08, \mathrm{p}=\mathrm{NS}$ & $\mathrm{R}=0.03, \mathrm{p}=\mathrm{NS}$ \\
\hline \multicolumn{4}{|c|}{ Correlations between serum concentrations of glucose and adipokines } \\
\hline All the participants & $R=0.29, p<0.001$ & $\mathrm{R}=-0.16, \mathrm{p}=\mathrm{NS}$ & $\mathrm{R}=0.07, \mathrm{p}=\mathrm{NS}$ \\
\hline Prostate cancer & $\mathrm{R}=0.24, \mathrm{p}<0.05$ & $\mathrm{R}=-0.10, \mathrm{p}=\mathrm{NS}$ & $\mathrm{R}=0.15, \mathrm{p}=\mathrm{NS}$ \\
\hline Prostate hypertrophia & $\mathrm{R}=0.33, \mathrm{p}<0.01$ & $\mathrm{R}=-0.24, \mathrm{p}<0.05$ & $\mathrm{R}=0.03, \mathrm{p}=\mathrm{NS}$ \\
\hline \multicolumn{4}{|c|}{ Correlations between serum concentrations of $\mathrm{cHDL}$ and adipokines } \\
\hline All the participants & $\mathrm{R}=0.03, \mathrm{p}=\mathrm{NS}$ & $R=0.27, p<0.01$ & $R=-0.15, p=N S$ \\
\hline Prostate cancer & $\mathrm{R}=0.06, \mathrm{p}=\mathrm{NS}$ & $\mathrm{R}=0.19, \mathrm{p}=\mathrm{NS}$ & $\mathrm{R}=-0.17, \mathrm{p}=\mathrm{NS}$ \\
\hline Prostate hypertrophia & $\mathrm{R}=0.01, \mathrm{p}=\mathrm{NS}$ & $\mathrm{R}=0.34, \mathrm{p}<0.01$ & $R=-0.10, p=N S$ \\
\hline \multicolumn{4}{|c|}{ Correlations between serum concentrations of triglycerides and adipokines } \\
\hline All the participants & $\mathrm{R}=0.17, \mathrm{p}<0.05$ & $\mathrm{R}=-0.28, \mathrm{p}<0.001$ & $\mathrm{R}=0.25, \mathrm{p}<0.01$ \\
\hline Prostate cancer & $\mathrm{R}=0.27, \mathrm{p}<0.05$ & $\mathrm{R}=-0.28, \mathrm{p}<0.01$ & $\mathrm{R}=0.37, \mathrm{p}<0.001$ \\
\hline Prostate hypertrophia & $\mathrm{R}=0.10, p=N S$ & $R=-0.29, p<0.01$ & $\mathrm{R}=0.12, \mathrm{p}=\mathrm{NS}$ \\
\hline
\end{tabular}

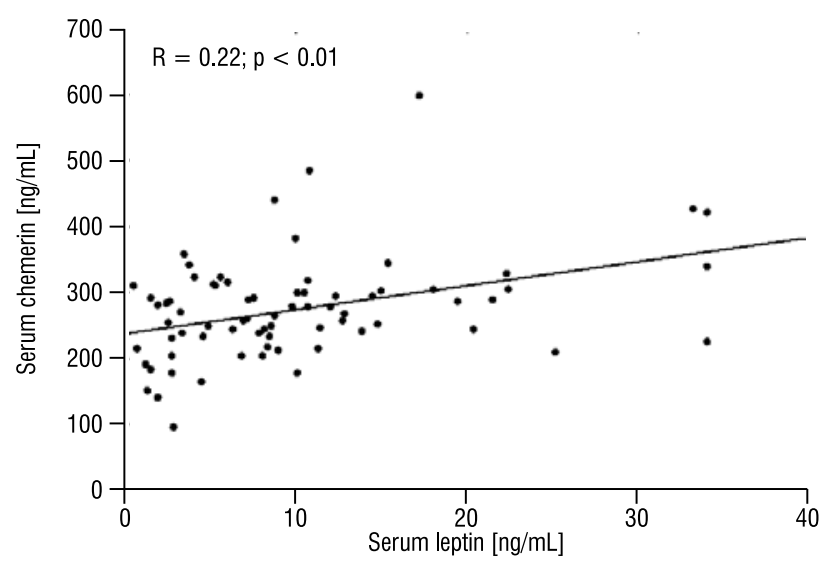

Figure I. Correlations between serum leptin and chemerin in men with prostate cancer

Rycina I. Korelacje pomiędzy stężeniem leptyny i chemeryny u mężczyzn z rakiem prostaty characterized by growing percentage of obesity during the last time [14]. It might significantly affect the obtained results.

Obesity may influence prostate cancer development and aggressiveness in various ways. One of the mechanisms linking obesity and cancerogenesis may be adipose tissue dysfunction with altered adipokines secretion and persistent inflammation [15]. Another potential factor to explain the link between obesity and cancer is hyperinsulinemia and increased IGF-I response to $\mathrm{GH}$ [16]. In this study we have focused on the serum concentrations of adipokines which concentrations are related to the adiposity: leptin, adiponectin and chemerin. Indeed, in our study we have observed correlations between adipokines and BMI, waist circumferences and different parameters of metabolic profile such as glucose, triglycerides and cHDL. 
Leptin concentrations are increased in obese patients and it is well documented that this hormone stimulates tumor cells growth and invasion. There is a growing evidence of its role in development of colorectal, hepatocellular, breast and thyroid cancer [17]. Observation that leptin receptors have high expression in the prostate proves leptin role in pathophysiology processes [18]. Different studies have evaluated a role of leptin in the pathogenesis of prostate cancer but the results are contradictory. Some authors reported that hyperleptinemia is associated with increased risk for prostate cancer $[19,20]$, but recently published data about this subject are inconsistent [21, 22]. In this study we have found that serum leptin levels were similar in prostate cancer and benign hyperplasia patients. However, subjects with poorly differentiated cancer had higher leptin levels than patients with well differentiated cancer. Our results are in agreement with the previously published data [23]. This association could be explained considering that hyperleptynemia promotes neoangiogenesis and prostate cancer cells proliferation. In our study leptin were correlated with IL-6 and with insulin resistance in both groups, however only in the cancer group we have demonstrated relationships between leptin and chemerin and between IL- 6 and chemerin. It is possible that leptin interacts with other hormones and cytokines and the crosstalking between them fosters cancerogenesis and invasion.

In this study we have observed that prostate cancer men exhibit elevated serum IL-6 concentrations when compared with benign prostate hyperplasia men. Our finding are in agreement with those obtained by other researchers [24,25]. Increased levels of this inflammatory cytokine modulate the expression of genes responsible for cell proliferation and angiogenesis via the JAK-STAT signaling pathway. Shariat et al described that increased inflammatory cytokines concentrations might be involved in prostate cancer aggressiveness [25]. In this study we have observed higher IL-6 levels in poorly differentiated cancer subgroup than in well differentiated prostate cancer subgroup and we have demonstrated relationships between IL- 6 and chemerin which also was connected with prostate cancer aggressiveness. It is possible that chronic inflammation which is associated with disturbed adipokine secretion and signaling, fosters prostate cancer development and growth.

Reduced serum adiponectin has been seen in a number of different cancers such as oesophageal, gastric, pancreatic, colorectal, hepatic, breast, endometrial cancer, lung and renal [26]. In our study we didn't observe the differences in serum adiponectin between prostate cancer and benign prostate hyperplasia and we didn ' $t$ demonstrate correlations with Gleason score, which was postulated by some researchers [27-29].
Results of studies examined relationships between serum adiponectin and prostate cancer are contradictory. AdipoR1 and AdipoR2 have been identified on both benign and malignant human prostate cells [30]. However, the epithelium of malignant prostatic glands showed an enhanced adiponectin expression in comparison with benign hyperplasia [30]. In vitro studies have demonstrated that adiponectin exerts effects on prostate cancer cells by modulating AMPK and PI3 kinase/Akt pathways [31]. Series studies have reported that patients with prostate cancer exhibited decreased serum adiponectin concentrations as compared in men with benign prostate cancer or in healthy controls [27-29]. Moreover, adiponectin was significantly and inversely connected with prostate stage or Gleason score [28]. Some authors described inverse associations only in overweight or obese men, but not in normal weight or in all men [32]. However, few studies are consistent with our observations and have excluded the potential relations between low adiponectin concentration and prostate cancer risk [22, 30,33]. In this study, adiponectin concentrations have reflected mainly metabolic status and have correlated with HOMA-I, cHDL and triglycerides levels in both cancer and benign hyperplasia groups. Furthermore, in cancer group adiponectin was connected with BMI and waist circumference. Besides, in all men and in the cancer group we have found significant correlations between adiponectin and PSA concentrations. Our results are in agreement with results of the study by Ikeda et al. who also have found the significant associations between adiponectin and PSA in almost 3000 Japanese men [34]. However, nature of those dependencies is unknown and there is a need for further clinical and experimental studies to resolve the nature of those relationships.

Although we didn ` $t$ detect significant differences in adiponectin or leptin levels, we have manifested significantly larger leptin-to-adiponectin ratio in cancer men in comparison to benign hyperplasia group. To the best of our knowledge this is the first study in which higher ratio was detected in prostate cancer men, regardless of anthropometric parameters. Although Tewari et al. have observed higher proportion between high leptin and low adiponectin in prostate cancer group, they have obtained results which were depended on different nutritional status of studied groups [35]. In the poorly differentiated cancer subgroup, subjects had higher leptin-to-adiponectin ratio. It is assumed that leptinto-adiponectin index represents more precise marker of adipose tissue dysfunction [36]. It suggests that not isolated adipokines are critical in the development of prostate cancer but imbalance between leptin and adiponectin may be a crucial moment in cancerogenesis and aggressiveness. 
Chemerin is an adipokine expressed and secreted predominantly by adipocytes which is associated with obesity and metabolic syndrome. This adipokine is involved in metabolism and immune reactions. Recently, the potential role of chemerin in cancerogenesis was described [37, 38]. Higher chemerin levels were observed in non-small cell lung cancer patients compared with healthy controls and were associated with advanced TNM stage [37]. Elevated serum levels of chemerin were also determined in gastric cancer and colorectal cancer patients [38]. To our knowledge, the relationship between chemerin and prostate cancer has not been investigated previously. Therefore, we assessed chemerin levels in prostate cancer men and compared with patients with diagnosed benign prostatic hyperplasia but we didn ' $t$ find the differences between groups. However, after subdividing prostate cancer group considering the Gleason score, it was found that chemerin concentrations has grown simultaneously with prostate cancer severity. Further studies are needed to explain the mechanism underlying this increase. It should be noted that in the cancer group the chemerin concentrations positively correlated with leptin, IL-6 levels and leptin-to-adiponectin ratio. In addition, chemerin levels were affected by nutritional status, as chemerin concentrations were proportional to BMI, waist circumferences and triglycerides levels. It is possible that cluster of adipokines and cytokines perturbation may contribute to cancerogenesis and aggressiveness of prostate cancer.

In summary, leptin-to-adiponectin ratio and IL-6 were elevated in men with prostate cancer. Leptin, chemerin, IL-6 and leptin-to-adiponectin ratio were associated with Gleason score but the relationships were dependent on each other. Overweight and obese men with prostate cancer were more likely to have moderately differentiated or poorly differentiated cancer than those with normal BMI.

\section{Funding sources}

Research relating to this manuscript was funded by grant of Medical University of Silesia.

\section{References}

1. De Nunzio C, Aronson W, Freedland SJ, et al. The correlation between metabolic syndrome and prostatic diseases. Eur Urol. 2012; 61(3): 560-570, doi: 10.1016/j.eururo.2011.11.013, indexed in Pubmed: 22119157.

2. Pérez-Hernández AI, Catalán V, Gómez-Ambrosi J, et al. Mechanisms linking excess adiposity and carcinogenesis promotion. Front Endocrinol (Lausanne). 2014; 5: 65, doi: 10.3389/fendo.2014.00065, indexed in Pubmed: 24829560.

3. Renehan AG, Tyson M, Egger M, et al. Body-mass index and incidence of cancer: a systematic review and meta-analysis of prospective observational studies. Lancet. 2008; 371(9612): 569-578, doi: 10.1016/S01406736(08)60269-X, indexed in Pubmed: 18280327.

4. Azevedo A, Cunha V, Teixeira AL, et al. IL-6/IL-6R as a potential key signaling pathway in prostate cancer development. World J Clin Oncol. 2011; 2(12): 384-396, doi: 10.5306/wjco.v2.i12.384, indexed in Pubmed: 22171281.
5. Giri D, Ozen M, Ittmann M. Interleukin-6 is an autocrine growth factor in human prostate cancer. Am J Pathol. 2001; 159(6): 2159-2165, doi: 10.1016/S0002-9440(10)63067-2, indexed in Pubmed: 11733366.

6. Matthews DR, Hosker JP, Rudenski AS, et al. Homeostasis model assessment: insulin resistance and beta-cell function from fasting plasma glucose and insulin concentrations in man. Diabetologia. 1985; 28(7): 412-419, indexed in Pubmed: 3899825.

7. Ibarra-Reynoso Ld, Pisarchyk L, Pérez-Luque EL, et al. Whole-body and hepatic insulin resistance in obese children. PLoS One. 2014; 9(11): e113576, doi: 10.1371/journal.pone.0113576, indexed in Pubmed: 25411786.

8. Calle EE, Rodriguez C, Walker-Thurmond K, et al. Overweight, obesity, and mortality from cancer in a prospectively studied cohort of U.S. adults. N Engl J Med. 2003; 348(17): 1625-1638, doi: 10.1056/ NEJMoa021423, indexed in Pubmed: 12711737.

9. Arnold M, Pandeya N, Byrnes G, et al. Global burden of cancer attributable to high body-mass index in 2012: a population-based study. Lance Oncol. 2015; 16(1): 36-46, doi: 10.1016/S1470-2045(14)71123-4, indexed in Pubmed: 25467404

10. Allott EH, Masko EM, Freedland SJ. Obesity and prostate cancer: weighing the evidence. Eur Urol. 2013; 63(5): 800-809, doi: 10.1016/j. eururo.2012.11.013, indexed in Pubmed: 23219374.

11. Wright ME, Chang SC, Schatzkin A, et al. Prospective study of adiposity and weight change in relation to prostate cancer incidence and mortality. Cancer. 2007; 109(4): 675-684, doi: 10.1002/cncr.22443, indexed in Pubmed: 17211863.

12. Tilki D, Schlenker B, John M, et al. Clinical and pathologic predictors of Gleason sum upgrading in patients after radical prostatectomy: results from a single institution series. Urol Oncol. 2011; 29(5): 508-514, doi: 10.1016/j.urolonc.2009.07.003, indexed in Pubmed: 19837614.

13. Kim H, Kalchman I, Santiago-Jiménez M, et al. Transcriptome evaluation of the relation between body mass index and prostate cancer outcomes. Cancer. 2017; 123(12): 2240-2247, doi: 10.1002/cncr.30580, indexed in Pubmed: 28140459.

14. Webber L. Projected incidence of overweight and obesity and related disease incidence across Poland. Cent Eur J Public Health. 2014; 22(1): 17-23, doi: 10.21101/cejph.a3877, indexed in Pubmed: 24844100.

15. Siemińska L. [Adipose tissue. Pathophysiology, distribution, sex differences and the role in inflammation and cancerogenesis]. Endokrynol Pol. 2007; 58(4): 330-342, indexed in Pubmed: 18058725.

16. Boguszewski CL, Boguszewski MC, Kopchick JJ. Growth hormone, insulin-like growth factor system and carcinogenesis. Endokrynol Pol. 2016; 67(4): 414-426, doi: 10.5603/EP.a2016.0053, indexed in Pubmed: 27387246.

17. Dutta D, Ghosh S, Pandit K, et al. Leptin and cancer: Pathogenesis and modulation. Indian J Endocrinol Metab. 2012; 16(Suppl 3): S596-S600, doi: 10.4103/2230-8210.105577, indexed in Pubmed: 23565495.

18. Cioffi JA, Shafer AW, Zupancic TJ, et al. Novel B219/OB receptor isoforms: possible role of leptin in hematopoiesis and reproduction. Nat Med. 1996; 2(5): 585-589, doi: 10.1038/nm0596-585, indexed in Pubmed: 8616721.

19. Stattin P, Söderberg S, Hallmans G, et al. Leptin is associated with increased prostate cancer risk: a nested case-referent study. J Clin Endocrinol Metab. 2001; 86(3): 1341-1345, doi: 10.1210/jcem.86.3.7328, indexed in Pubmed: 11238530.

20. Lagiou P, Signorello LB, Trichopoulos D, et al. Leptin in relation to prostate cancer and benign prostatic hyperplasia. Int J Cancer. 1998; 76(1): 25-28, doi: 10.1002/(sici)1097-0215(19980330)76:1<25::aidijc5 > 3.0.co;2-\#, indexed in Pubmed: 9533757.

21. Lai GY, Giovannucci EL, Pollak MN, et al. Association of C-peptide and leptin with prostate cancer incidence in the Health Professionals Followup Study. Cancer Causes Control. 2014; 25(5): 625-632, doi: 10.1007/ s10552-014-0369-3, indexed in Pubmed: 24664287.

22. Li H, Stampfer MJ, Mucci L, et al. A 25-year prospective study of plasma adiponectin and leptin concentrations and prostate cancer risk and survival. Clin Chem. 2010; 56(1): 34-43, doi: 10.1373/clinchem.2009.133272, indexed in Pubmed: 19910504.

23. Mistry T, Digby JE, Desai KM, et al. Obesity and prostate cancer: a role for adipokines. Eur Urol. 2007; 52(1): 46-53, doi: 10.1016/j.eururo.2007.03.054, indexed in Pubmed: 17399889.

24. Chung TD, Yu JJ, Spiotto MT, et al. Characterization of the role of IL-6 in the progression of prostate cancer. Prostate. 1999; 38(3): 199-207, doi: 10.1002/(sici)1097-0045(19990215)38:3<199::aid-pros4>3.0.co;2-h, indexed in Pubmed: 10068344

25. Shariat SF, Kattan MW, Traxel E, et al. Association of pre- and postoperative plasma levels of transforming growth factor beta(1) and interleukin 6 and its soluble receptor with prostate cancer progression. Clin Cancer Res. 2004; 10(6): 1992-1999, doi: 10.1158/1078-0432.ccr-0768-03, indexed in Pubmed: 15041717.

26. Katira A, Tan $\mathrm{PH}$. Evolving role of adiponectin in cancer-controversies and update. Cancer Biol Med. 2016; 13(1): 101-119, doi: 10.28092/j. issn.2095-3941.2015.0092, indexed in Pubmed: 27144066 
27. Michalakis K, Williams CJ, Mitsiades N, et al. Serum adiponectin concentrations and tissue expression of adiponectin receptors are reduced in patients with prostate cancer: a case control study. Cancer Epidemiol Biomarkers Prev. 2007; 16(2): 308-313, doi: 10.1158/1055-9965.EPI-06-0621, indexed in Pubmed: 17301264.

28. Goktas S, Yilmaz MI, Caglar K, et al. Prostate cancer and adiponectin. Urology. 2005; 65(6): 1168-1172, doi: 10.1016/j.urology.2004.12.053, indexed in Pubmed: 15922427.

29. Arisan ED, Arisan S, Atis G, et al. Serum adipocytokine levels in prostate cancer patients. Urol Int. 2009; 82(2): 203-208, doi: 10.1159/000200801, indexed in Pubmed: 19322011.

30. Housa D, Vernerová Z, Herácek J, et al. Adiponectin as a potential marker of prostate cancer progression: studies in organ-confined and locally advanced prostate cancer. Physiol Res. 2008; 57(3): 451-458, indexed in Pubmed: 17465703.

31. Huang M, Koizumi A, Narita S, et al. Diet-induced alteration of fatty acid synthase in prostate cancer progression. Oncogenesis. 2016; 5: e195, doi 10.1038/oncsis.2015.42, indexed in Pubmed: 26878389.

32. Ikeda A, Nakagawa T, Kawai K, et al. Serum adiponectin concentration in 2,939 Japanese men undergoing screening for prostate cancer. Prostate Int. 2015; 3(3): 87-92, doi: 10.1016/j.prnil.2015.07.001, indexed in Pubmed: 26473150 .
33. Freedland SJ, Sokoll LJ, Platz EA, et al. Association between serum adiponectin, and pathological stage and grade in men undergoing radical prostatectomy. J Urol. 2005; 174(4 Pt 1): 1266-1270, doi: 10.1097/01. ju.0000173093.89897.97, indexed in Pubmed: 16145390.

34. Baillargeon J, Platz EA, Rose DP, et al. Obesity, adipokines, and prostate cancer in a prospective population-based study. Cancer Epidemiol Biomarkers Prev. 2006; 15(7): 1331-1335, doi: 10.1158/1055-9965.EPI-06-0082, indexed in Pubmed: 16835332

35. Tewari R, Rajender S, Natu SM, et al. Significance of obesity markers and adipocytokines in high grade and high stage prostate cancer in North Indian men - a cross-sectional study. Cytokine. 2013; 63(2): 130-134, doi 10.1016/i.cyto.2013.04.008, indexed in Pubmed: 23669251.

36. Kappelle PJ, Dullaart RPF, van Beek AP, et al. The plasma leptin/adiponectin ratio predicts first cardiovascular event in men: a prospective nested case-control study. Eur J Intern Med. 2012; 23(8): 755-759, doi 10.1016/j.ejim.2012.06.013, indexed in Pubmed: 22819464.

37. $\mathrm{Xu} \mathrm{CH}$, Yang $\mathrm{Y}$, Wang YC, et al. Prognostic significance of serum chemerin levels in patients with non-small cell lung cancer. Oncotarget. 2017; 8(14): 22483-22489, doi: 10.18632/oncotarget.14956, indexed in Pubmed: 28160556.

38. Wang C, Wu WKK, Liu X, et al. Increased serum chemerin level promotes cellular invasiveness in gastric cancer: a clinical and experimental study. Peptides. 2014; 51: 131-138, doi: 10.1016/j.peptides.2013.10.009, indexed in Pubmed: 24274970. 